\title{
THE AGE OF KARST RELIEF IN WEST SLOVENIA
}

\section{STAROST KRAŠKEGA RELIEFA V ZAHODNI SLOVENIJI}

\author{
Andrej MIHEVC ${ }^{1}$
}

\begin{abstract}
UDC 551.435.8 (497.4 Kras)

Andrej Mihevc: The age of Karst relief in west Slovenia

The age of a karst can be defined as the time when the karst rocks were uplifted out of the sea. The other view of the age of karst is to define the age of certain karst features or assemblages of karst features. On the Kras plateau there is a variety of forms that were formed at quite different times, but due to karst evolution, they coexist in today's relief. On the plateau, that is slowly rising, the hydrological zones in karst surface are moving downwards. Streams from the side ceased to flow on the karst and former leveled surface that was formed in conditions of high ground water is dissected by numerous dolines. Blind valleys are incised at the side and some of them show the influence of recent tectonics. The lowering of relief by corrosion exposes caves that have formed deep beneath the surface and creates unroofed caves that become a part of the surface topography. From the morphological comparison of the unroofed caves, blind valleys and levelled surfaces and by dating of the sediment and considering the age of tectonic phases we can reconstruct the evolution and estimate the age of the karst landscape.

Key words: karst, morphology, age, Kras, Slovenia.
\end{abstract}

Izvleček UDK 551.435.8 (497.4 Kras)

Andrej Mihevc: Starost kraškega reliefa $v$ zahodni Sloveniji

Starost krasa lahko določimo s trenutkom, ko so bile kraške kamnine dvignjene iz morja. Drugi način opredelitve starosti krasa je $\mathrm{z}$ datiranjem reliefnih oblik ali skupin reliefnih oblik. Planoto Kras sestavlja vrsta zelo različnih reliefnih oblik, ki so nastale v različnem času, vendar so se zaradi posebnosti razvoja krasa ohranile in sobivajo v sedanjem reliefu. Na planoti, ki se počasi dviguje se hidrološke cone in kraško površje pomikajo navzdol. Vodotoki s strani so prenehali dotekati na kras in nekdanje v višini talne vode nastalo uravnano površje so razčlenile številne vrtače. Na robu krasa so vrezane slepe doline, nekatere od njih kažejo sledove tudi recentnih tektonskih premikov. Zniževanje reliefa zaradi korozije je razgalilo jame, ki so se oblikovale globoko pod površjem in ustvarilo brezstrope jame, ki so postale del današnje topografije površja. $\mathrm{Z}$ morfološko primerjavo brezstropih jam, slepih dolin in uravnav in datiranjem sedimentov ter upoštevanjem starosti tektonskih faz lahko rekonstruiramo razvoj reliefa in ocenimo starost kraške pokrajine.

Ključne besede: kras, morfologija, starost, Kras, Slovenija.

\section{INTRODUCTION}

The question about time, like velocity of processes or age of karst surfaces and caves is a very important issue in karst studies. The age and evolution of karst is also important when we study karst as a specific ecosystem. It can tell us when karst and especially the caves start to form in a given area and how the landscape is changing.
The first explanation of geomorphic evolution and the age of the karst in W Slovenia were made by geologists. To estimate the age they used geologic data - the age of last marine sedimentation and the tectonic evolution of Dinaric mountains and the Alps (Grund 1914).

${ }^{1}$ Karst Research Institute, ZRC SAZU, Titov trg 2, Sl - 6230 Postojna, Fax: +386 5 7001999, Andrej.Mihevc@guest.arnes.si Received/Prejeto: 01.02.2007 


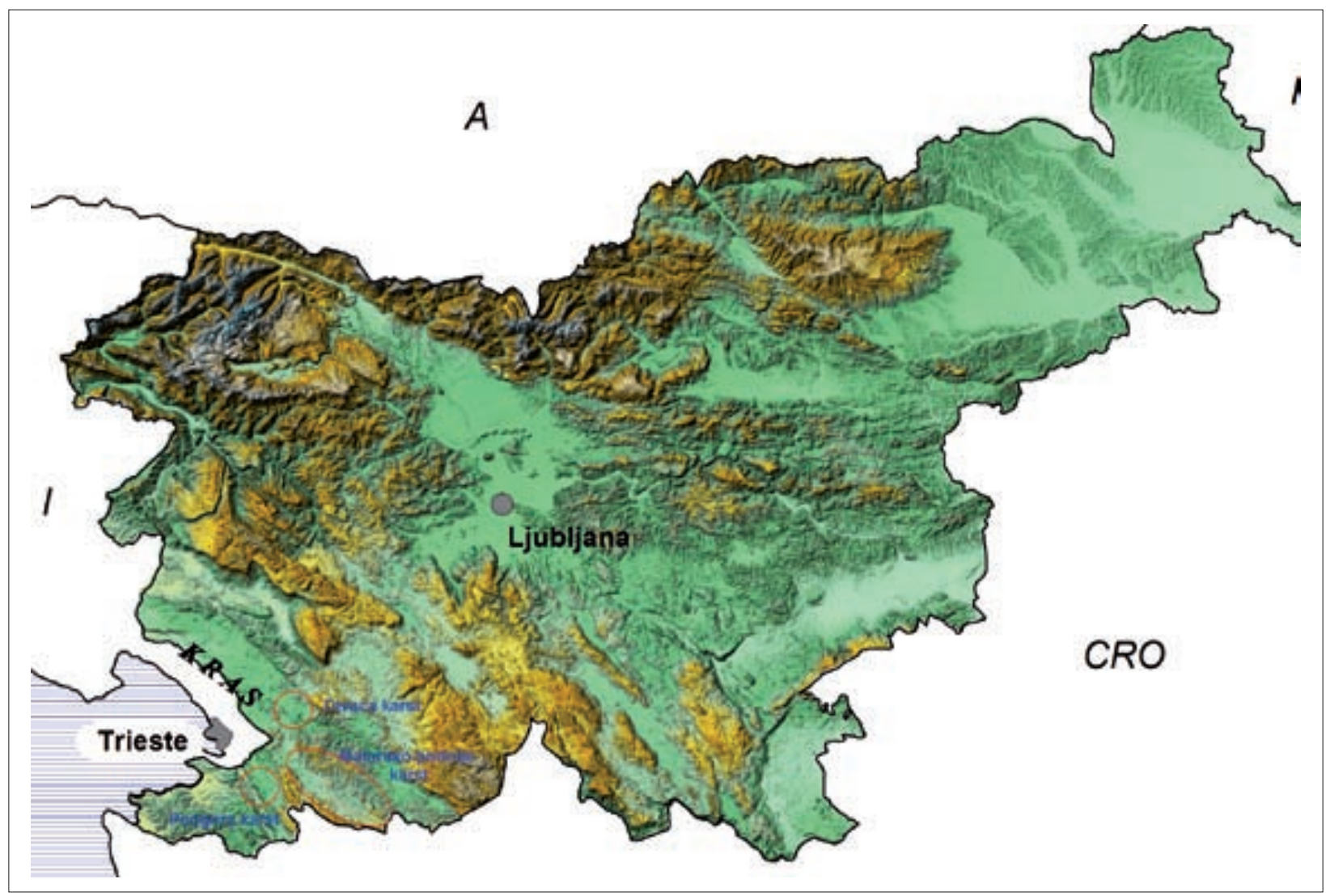

Fig. 1: The location of the Kras plateau and the study areas.

At first karstologists were focused on understanding karst processes and the evolution of karst features like dolines, poljes and corrosion plains. They were much influenced by the ideas of a geographic cycle promoted by Cvijić (1924). Karst evolution was divided into similar steps in the cycle but they also added a pre-karst phase of relief evolution with which they explained some morphological elements in karst.

The cyclic explanation of the karst evolution was later modified with climatic geomorphology (Roglič 1957, Radinja 1972). It emphasised the importance of climate on the morphological processes. This meant that some forms of relief, like conical hills and levelled surfaces were explained as a relicts from tropical climate. Because such a climate was present at the end of the Tertiary, these forms were determining the age of that relief features.

Another important climatic signal in the morphology of the Kras they estimate were the cold Pleistocene climates with periglacial processes in lower positions. Scree slopes, collapses in caves, fluvial deposits in contact karst areas and some finer sediment were explained as extremes of climate control and not normal karst phenomena. They were also used for determination of the age of features (Melik 1955, Gospodarič 1985).
Geomorphologists have abandoned the cyclic model of relief and are now paying more attention to structural elements in karst morphology like recent tectonic (Habič, 1982), field measurements and observations on karst denudation (Gams 1963), comparative studies of different karst features or types of karst, like contact karst (Gams 1962, Mihevc 1994), the study of dolines and collapsed dolines (Mihevc 2001) and new geomorphologic features like unroofed caves (Mihevc 1996, 2001, Slabe 1997) as an important remnants of former landscapes and a source of sediments. Flowstones in the caves were dated (Hajna 1991, Mihevc 2001) and paleomagnetic methods were used in cave and karst sediments (Bosak \& al. 1999, 2004).

Very important data were provided by latest research on the plate tectonics. The tectonic evolution of the area is characterized since late Tertiary first by northward motion of Adria micro plate which caused contraction deformations. The contraction was exhausted at about 6 Ma ago and was followed by rotation accompanied with uplifts, folding and strike-slip basins formation. These events take place in two distinct phases (Vrabec \& al. 2006, Fodor \& al. 1998). 


\section{GEOMORPHIC EVIDENCES ON THE AGE OF KRAS}

Kras is a low NW - SE trending longitudinal plateau along Trieste Bay (Adriatic Sea) between flysch Brkini hills on SE, Vipava Valley in NE, and the Soča River lowlands in NW. The plateau is about $45 \mathrm{~km}$ long and $14 \mathrm{~km}$ wide. The surface of the plateau is slightly tilted from 500 $\mathrm{m}$ a.s.l on SE towards NE where it ends at about $100 \mathrm{~m}$ above the Soča river.

The central part of Kras is built from highly permeable Cretaceous carbonate platform shallow marine limestone and less permeable dolomite. Eocene flysch that acts as an important impermeable barrier surrounds the carbonate massif.

The age of the karst of Kras plateau can be defined as the time when the karst rocks were uplifted out of the sea. For the most of Dinaric karst in Slovenia this occurred after the Eocene, since after that there is there is no evidence of younger marine sediments. As soon as the carbonate rocks were exposed, we can expect that the karst was formed, but there are no remnants of karst features from that time. Most likely denudation has destroyed them.
The other view on the age of karst is to define the age of those karst features for which we know how and when they were formed and which evolution was stopped long time ago. Such features are levelled surfaces, which evolve at the level of the karst water and blind valleys that were formed by alogenic rivers. We can compare them with evolution of fluvial relief and unroofed caves, which are caves exposed to surface by denudation.

On the Kras plateau there is a variety of forms that were formed at quite different conditions and time but due to peculiarities of karst evolution they coexist in today's relief. This can make the determination of the one age of a karst landscape difficult or impossible, but it tells us about the genesis of the landscape trough different phases.

Here we present the study of the part of the Kras, Divaški kras and Matarsko podolje and the edge of Podgorski kras from which there are some evidences about the evolution and age of Kras.

\section{THE UNROOFED CAVES OF DIVAŠKI KRAS}

The Divaški kras is tilted slightly towards NW at elevations between 450 and $400 \mathrm{~m}$ a.s.l, on the SE part of the Kras plateau. It is built up mostly by Cretaceous and Paleogene limestone. The karst features here are exceptional; there are the sinking of the Reka river into Škocjanske jame cave via large collapse dolines with and hundreds of dolines. The largest caves of the area are the 12,500 $\mathrm{m}$ long and $275 \mathrm{~m}$ deep Kačna jama and the 5800 $\mathrm{m}$ long and $250 \mathrm{~m}$ deep Škocjanske jame. The caves were formed by the Reka river which can be reached at a depth of $195 \mathrm{~m}$ in Škocjanske jame and $156 \mathrm{~m}$ a.s.l. in Kačna jama.

The main morphologic features of the area are collapsed dolines and dolines which together cover about $12 \%$ of the area. The collapsed dolines are connected with active water caves. The solution dolines cover less than $4 \%$ of the area. The rest of the surface (88\%) is level. These points out the prevailing surface leveling process in the present conditions

In this levelled surface there are several large unroofed caves (Mihevc 1996). As such caves appear on the surface due to denudation, and we may call their remains denuded caves. A cave ceiling will be the first to be removed by denudation, which is why they are also called unroofed caves. They were first found and described in the Divača Karst. The unroofed caves share on the surface is small, only about $0.16 \%$ of the entire surface.

Three important unroofed caves have been found. The first is a $350 \mathrm{~m}$ long unroofed cave near Povir village at $400 \mathrm{~m}$ above the sea level. There is a remnant of a cave passage that was $6 \mathrm{~m}$ wide and over $5 \mathrm{~m}$ high. The entire volume of the passage has been filled by allochtonous fluvial sediments of clay, silicate sands and gravel with pebbles up to $25 \mathrm{~cm}$ in diameter.

The second is an unroofed cave near Divača on the slopes of doline Radvanj at the altitude of $390-415 \mathrm{~m}$ above sea level. It is exposed on the slope that dissects large cave passage, which is entirely filled with sediments. Similar sediments can be seen in the Divaška jama cave. This is a $600 \mathrm{~m}$ long cave, whose continuation towards $250 \mathrm{~m}$ distant unroofed cave is completely filled. The cave was also filled, but the sediment was later washed from it by the seepage water. Here we can see that a part of the unroofed cave that still exists as an underground cave.

The longest roofless cave is $1.800 \mathrm{~m}$ long remnant of caves whose passages were about $20 \mathrm{~m}$ large, and therein flew a great underground river. The cave was filled with fluvial sediments and massive flowstone. It is located 


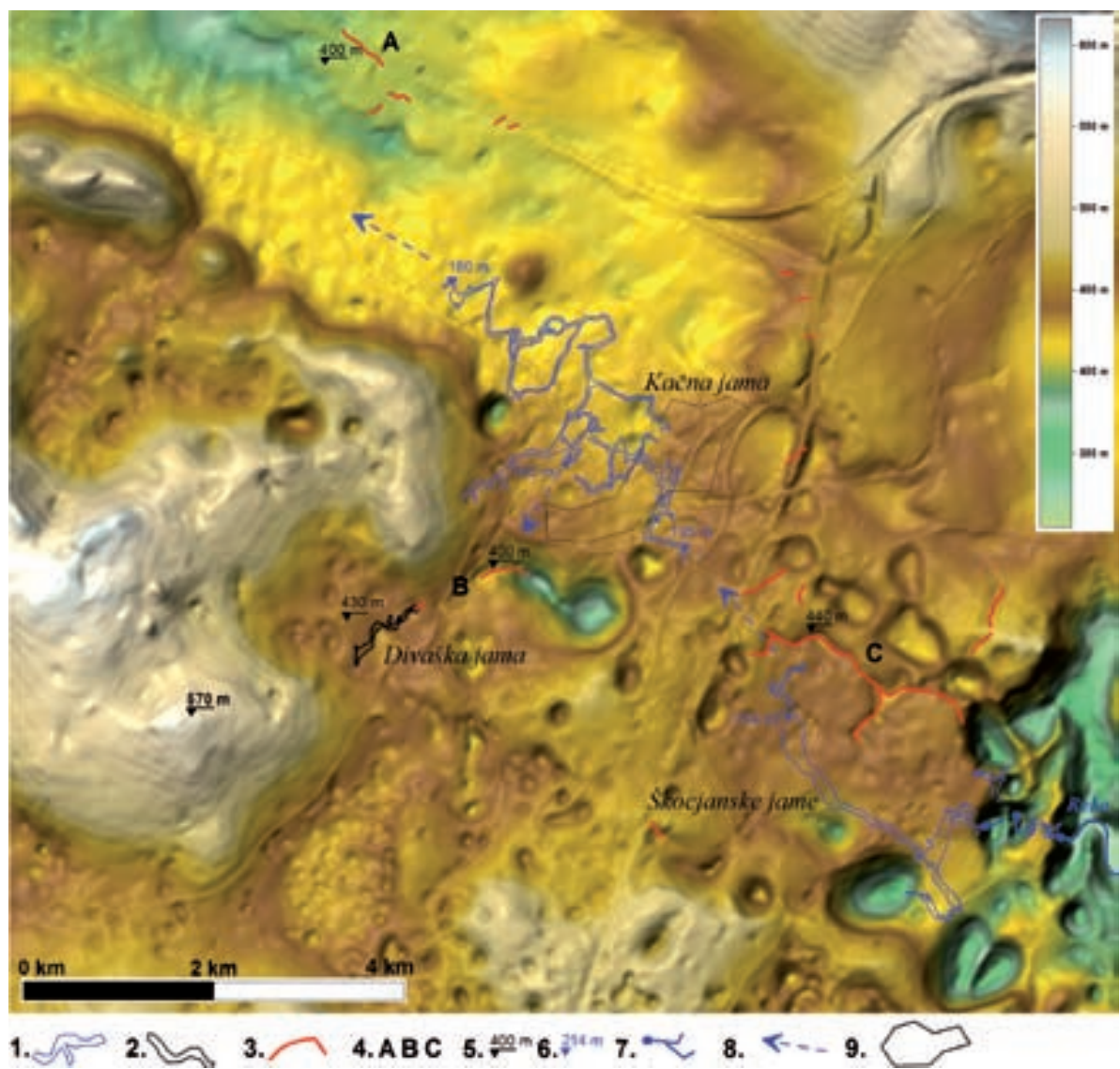

Fig. 2: The map of the Divača karst. On the levelled surface the large collapse dolines are dominating features, solution dolines are frequent, but they represent only small proportion of the surface. The outlines of the main caves and the main unroofed caves are marked. On the map made of DEM with $12.5 \mathrm{~m}$ grid the road cuts or causeways are also seen.

Legend: 1. Outline of the active river caves, 2. Divaška jama cave, 3. Unroofed cave, 4. Unroofed caves mentioned in the text: A: Unroofed cave near Povir, B: Unroofed cave in doline Radvanj, continuation of Divaška jama, C: Unroofed cave above Škocjanske jame, 5. Height of the surface, 6. Height of the water level in caves, 7. Reka river and ponors, 8. The supposed direction of water flow, 9. Outline of the town Divača.

partly above the Škocjanske jame, where the actual river bed in the cave is $230 \mathrm{~m}$ below the unroofed cave.

On the basis of the shape of walls and sediments we may reconstruct some evolution of the caves and later the surface. The caves are remnants of larger cave sys- tems, which conducted waters from different sinking streams. Growth of speleothems in them was frequently interrupted by phases of erosion or backfill. The caves were afterwards filled up with fluvial sediments. The large pebbles in the caves testify the great gradient of the surface streams. Later all caves were filled with finer sediment, which could mean the lowering of the gradient in karst and aplanation. Later, the surface was tilted and uplifted which caused lowering of the karst water level.

The age of the unroofed caves can be established by comparative methods according the denudation rate of the surface. If we presume, that it is about $50 \mathrm{~m} /$ Ma (Gams 1962) and there was some $100 \mathrm{~m}-200 \mathrm{~m}$ of rock removed from above the caves that they are at least 2 4 Ma old, and probably older (Mihevc 1996, 2001).

Similar time frames 1.6 - $1.8 \mathrm{Ma}$ or/and 3.8 to $5 \mathrm{Ma}$ were given also by paleomagnetic datation of clastic sediments (Bosak \& al. 1998) and by the timing with tectonic phase that started at $6 \mathrm{Ma}$ (Vrabec \& al. 2006).

The age of the roofless cave can also be illustrated by the time, in which the water table in Kras lowered for 240 $\mathrm{m}$, from about $400 \mathrm{~m}$ to $160 \mathrm{~m}$ a.s.l. 


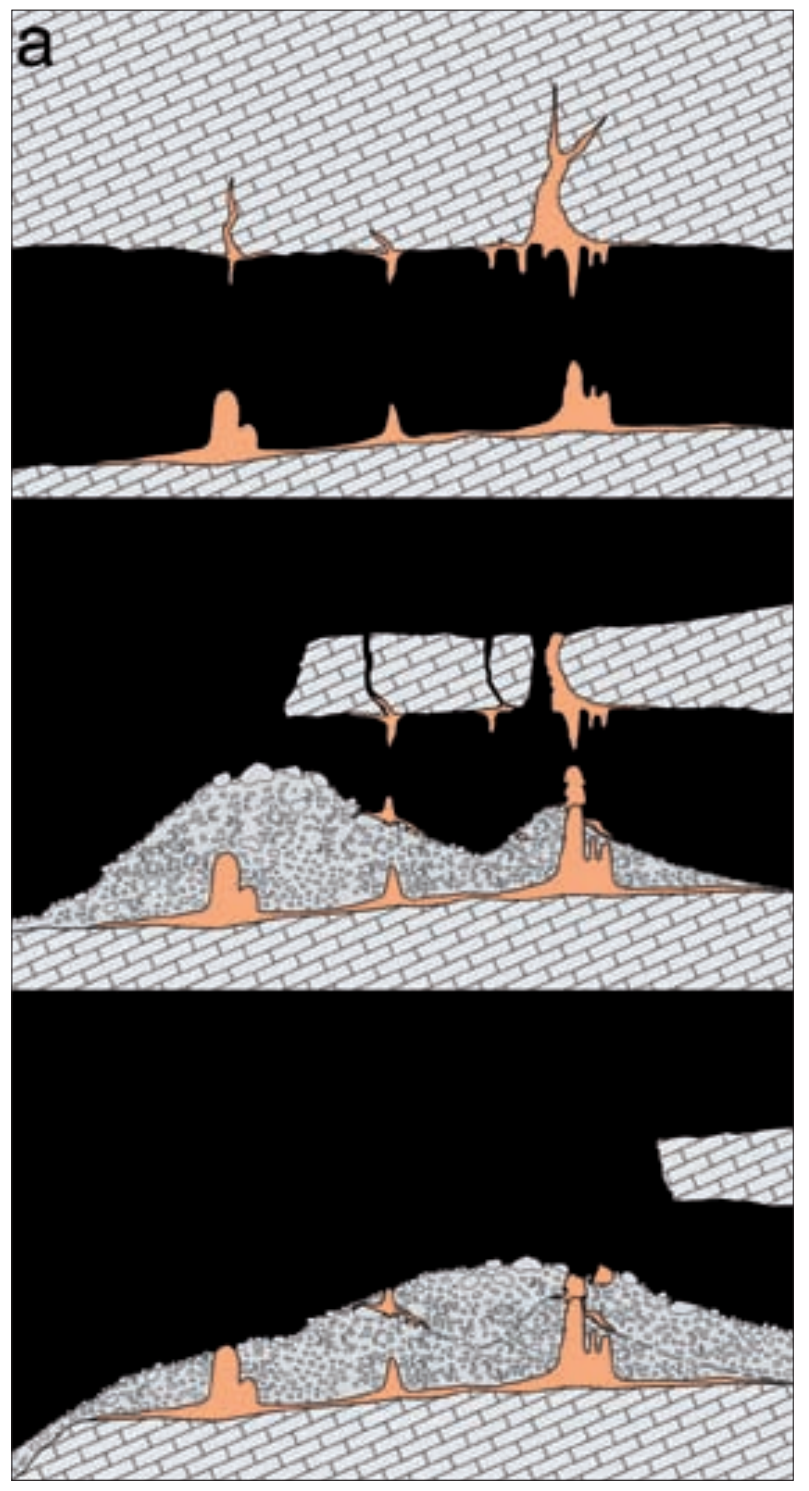

Fig. 3: Formation of the unroofed cave. The idealised drawing is representing actual cases of unroofed or partly denuded caves from the Divača karst, where probably more than hundred meters of the rock above unroofed caves were removed. The transformation of cave to the unroofed cave is here presented in three stages: a: Epiphreatic cave passage was formed deep below the surface, some flowstone was deposited after the cave became inactive; $b$ : Surface approached the cave. At one side the slope cut the cave and made the entrance into the passage; from the horizontal surface former vadose shafts transformed into vertical entrance. Trough both entrances piles of boulders and scree deposited. $c$ : Great deal of the ceiling dissolved, some collapsed and formed relief oblong depression of the unroofed cave ending in front of the entrance to the cave.

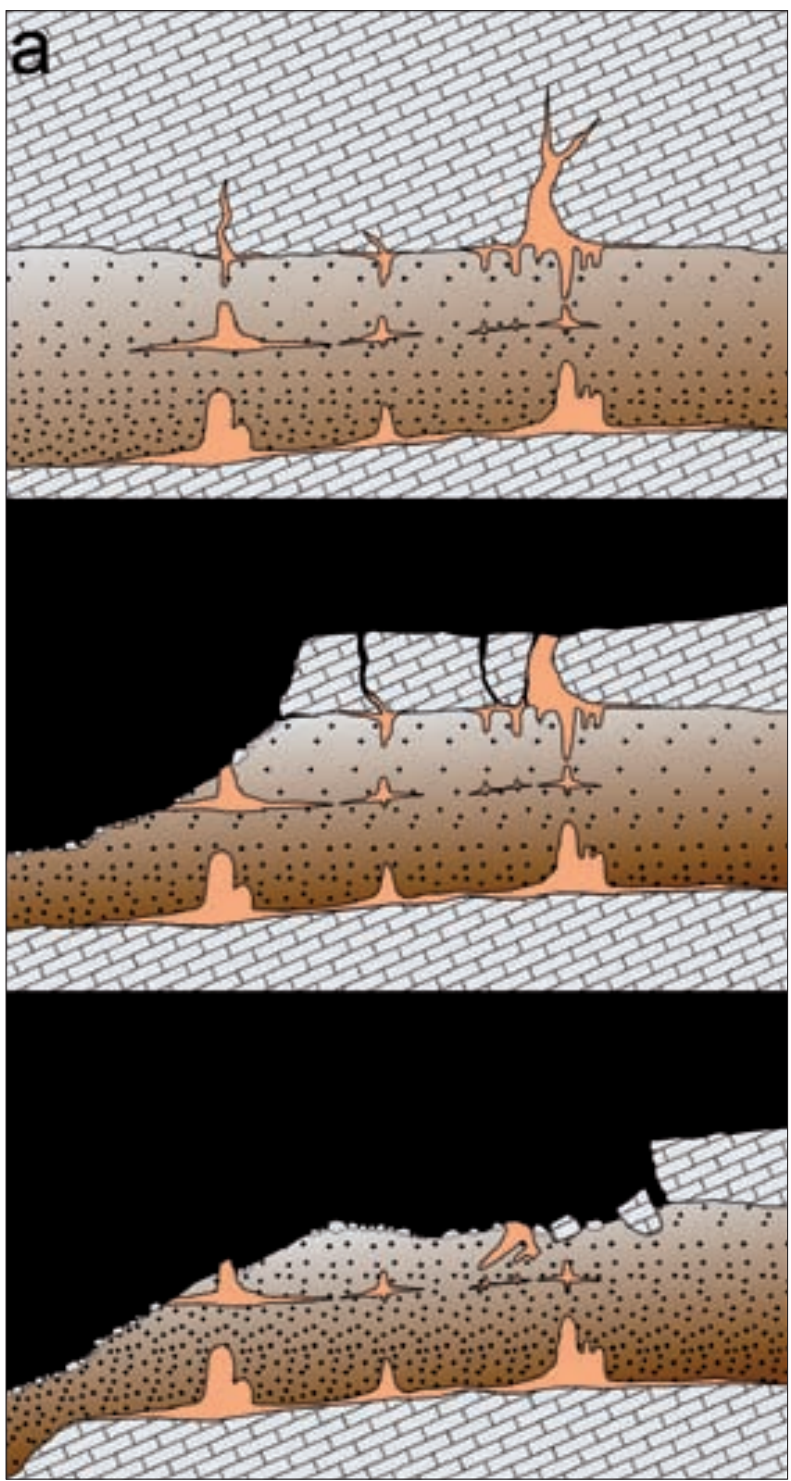

Fig. 4: Formation of the unroofed cave. The idealised drawings are representing the actual cases of unroofed or partly unroofed caves from the Divača karst which were completely filled with allogenic fluvial sediment.

The transformation is here presented in three stages: a: Cave passage was formed deep below the surface. There was alternation of the sedimentation of flowstone and allogenic sediments of the underground river. Towards the top of the profile sediments became finer. b: Surface approached the cave. At the side the slope cuts passage and exposed the cave sediments on the surface. c: After disintegration of the ceiling from the top oblong depression formed. In it there are alochtonous sediments and few blocks of limestone and some flowstone. The unroofed cave ends with steep limestone wall or slope from where the karst surface continues. 


\section{THE BLIND VALLEYS OF THE MATARSKO PODOLJE CONTACT KARST}

Alogene rivers flowing to karst enhance the karstification process and form particular relief features. Phenomena and forms that develop at the contact of fluvial and karst relief are the result of the interaction of both morphological systems.

The Matarsko Podolje is a $25 \mathrm{~km}$ long and 2-5 km wide tilted karst surface. In longitudinal section it gently raises from about $490 \mathrm{~m}$ on NW to $650 \mathrm{~m}$ on SE side. The karst surface continues towards SE but from the highest point there is an abrupt change and relief lowers over the distance of $2 \mathrm{~km}$ for $200 \mathrm{~m}$ to Brgudsko podolje karst surface.

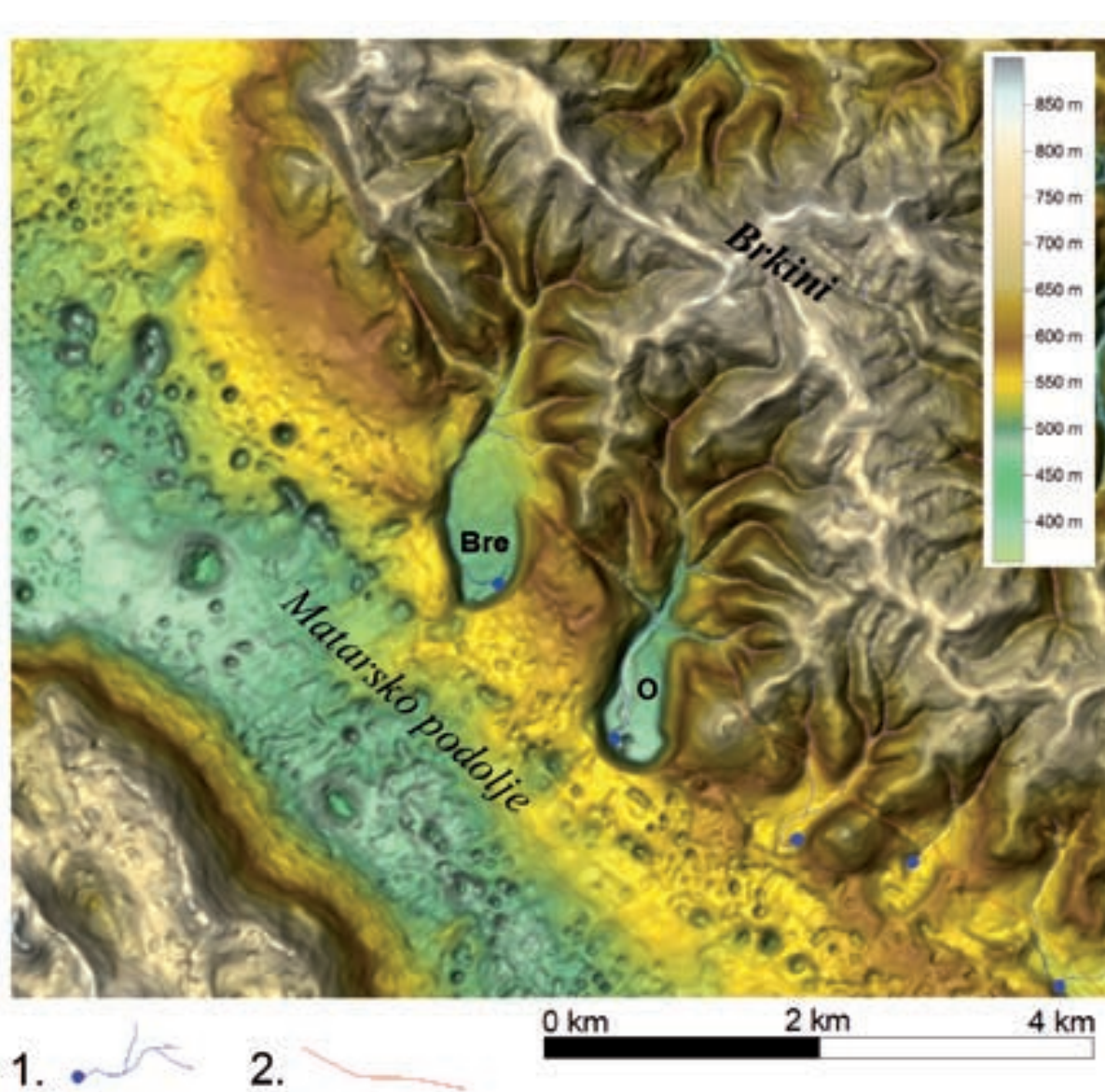

Fig. 5: Blind valleys Brezovica (Br) and Odolina (O) on the NW part of the Matarsko podolje karst. Blind valleys cut for about $50 \mathrm{~m}$ into the edge of the levelled karst surface where dolines and larger collapse dolines prevail. There are no traces of dry valleys or dry blind valleys.

Legend: 1. Sinking streams, 2. Boundary flysch-limestone.

From the flysch Brkini hills that are NE of podolje there are 17 sinking streams that formed a row of large blind valleys in the edge of the Matarsko Podolje. The bottoms of these valleys are situated between 490 to 510 $\mathrm{m}$. As the valleys are incised in the border of the karst, uplifted towards SE, the blind valleys lying more to the south are deeper. The most NW lying, Brezovica and Odolina blind valley are cut for about $50 \mathrm{~m}$ only while the deepest is the last one, Brdanska dana on SE, deepened into limestone for $250 \mathrm{~m}$.

The blind valleys started to cut into the corrosion plain with small transverse and longitudinal gradient as in the other case the fluvial valleys should develop in them. They should be preserved on karst as dry valleys. The corrosion plains along the ponors were controlled by the piezometric level this is why they are all at same altitude.

In the SE part where the uplift was stronger, the blind valleys show the disturbances caused by fast tectonic uplift and are preserved on the karst surface. Above the Račiška Dana blind valley there is a fossil one, on the bottom of which are some old sediment from flysch. This is now higher than the flysch hills where the sediment came from. The other case is the most SE blind valley Brdanska Dana. It developed in the SE edge of the Matarsko Podolje. The tectonic structure along which the Matarsko Podolje ends caused also the asymmetric development of the blind valley. The $\mathrm{W}$ side of the blind valley was uplifted and developed two fossil higher levels in the side of the blind valley.

The Brkini series of blind valleys offer enough data to follow the sequence of the morphological events and dominant factors which were decisive for the formation of the actual relief forms. The former shape along the ponors on the border of impermeable hills was karst corrosion plain. The water flowing on it had a modest gradient in karst and was capable of the aplanation of the surface only. The lowering of the piezometric level in the karst enabled the development of the relief depressions along the ponors. The deepen- 


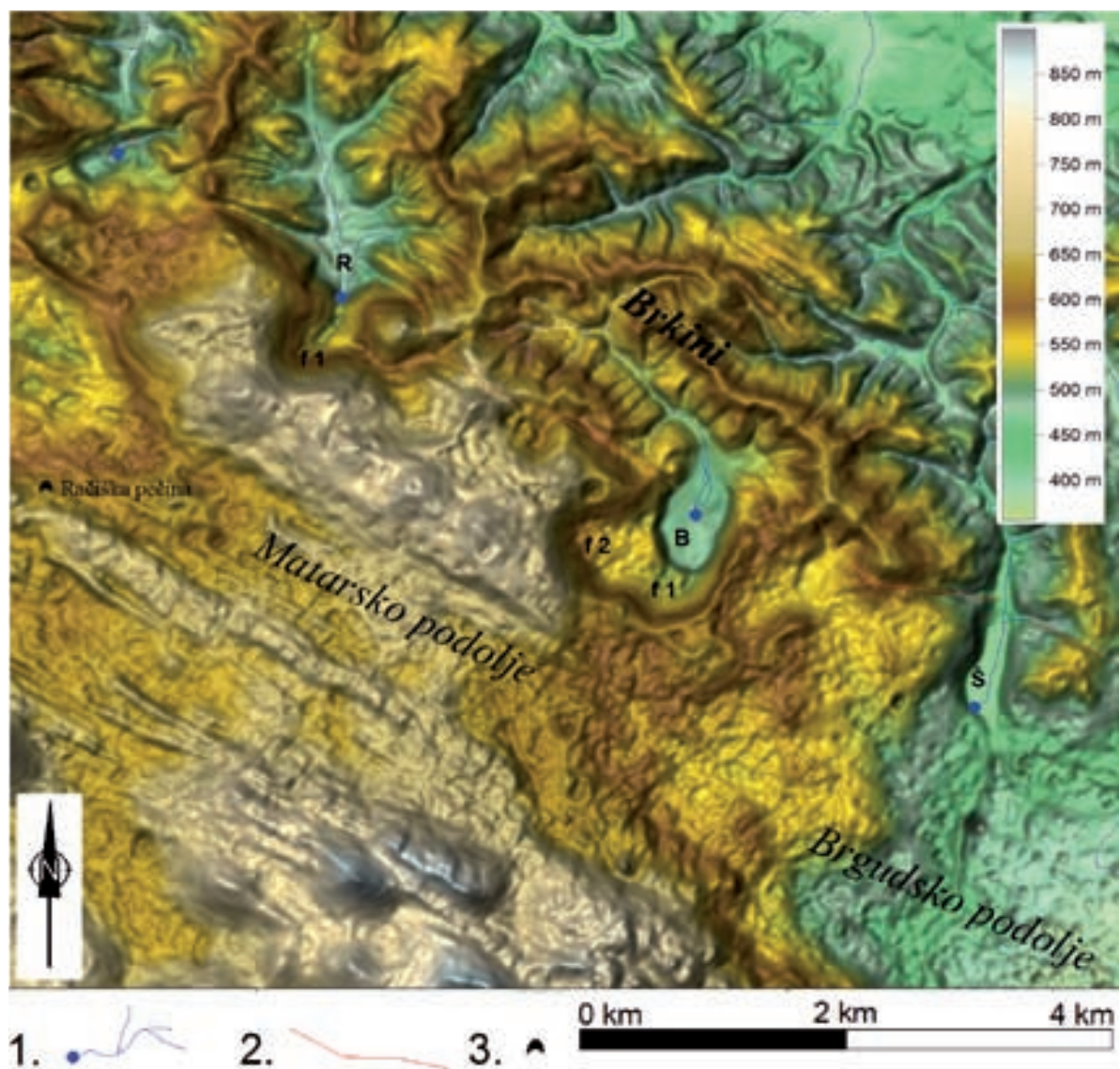

Fig. 6: Blind valleys Račiška dana $(R)$ and Brdanska dana (B) with fossil blind valleys $(f 1, f 2)$. These valleys developed in SE part of Matarsko podolje during the tectonic uplift. Uplift deformed older corrosion plain and created height difference between Matarsko and Brgudsko podolje. Further SE there is another blind valley $(\breve{S})$ which developed at the edge of Brgudsko podolje that was not uplifted. Račiška pečina cave that was once formed by sinking streams is at elevation about $600 \mathrm{~m}$ high above the recent ponors.

Legend: 1. Sinking streams, 2. Boundary flysch - limestone, 3. Cave Račiška pečina. ing and the contemporaneous widening of the valleys followed the lowering of the karst water to the altitudes about $500 \mathrm{~m}$.

The incision of blind valleys into the leveled surface probably started and continued trough the last tectonic phase that is $6 \mathrm{Ma}$ before present. This is also accordance with the age of the cave sediments from Račiška pečina which were dated by paleomagnetic method and correlated with palaeontologic data to $3.5 \mathrm{Ma}$ (Pruner \& al. 2003).

\section{THE UNROOFED CAVES OF THE EDGE OF THE PODGORSKI KRAS}

Podgora karst is small $5 \mathrm{~km}$ wide and long karst plateau, SW continuation of the Kras. Its surface is located at 500 to $450 \mathrm{~m}$ a.s.l. The plateau surface is leveled and dismembered only by numerous dolines. There is a sharp edge of the plateau and towards $\mathrm{W}$ in less than $1 \mathrm{~km}$ relief drops for $400 \mathrm{~m}$. At the foot of the plateau there are recent karst springs of the rivers Rižana and Osapska reka at altitudes of about $50 \mathrm{~m}$ a.s.l.

In the Črnotiče quarry, that is located on the edge of the plateau, several caves were opened. Shafts with stalagmites and stalactites on the walls were filled by gravel as well as numerous bones of large Pleistocene mammals felt down to shafts.
There are also large remnants of horizontal caves. The largest, $150 \mathrm{~m}$ long partly unroofed passage with the diameter of more than $10 \mathrm{~m}$ was opened in the western part of the quarry. The passage was entirely filled by massive flowstones deposited over the fluvial sediments, layers of gravel and conglomerate mixed up with sand and clay layers. Sedimentary fill was $17 \mathrm{~m}$ thick at least.

In the cave calcareous tubes a serpulids were found both in sediments and still attached to the scalloped wall. They match the morphology of extant serpulid tubes of Marifugia cavatica (Mihevc 2000; Mihevc et al., 2001a). Marifugia cavatica Absolon and Hrabe, 1930 is the only fresh-water species of the Serpulidae family and the only 


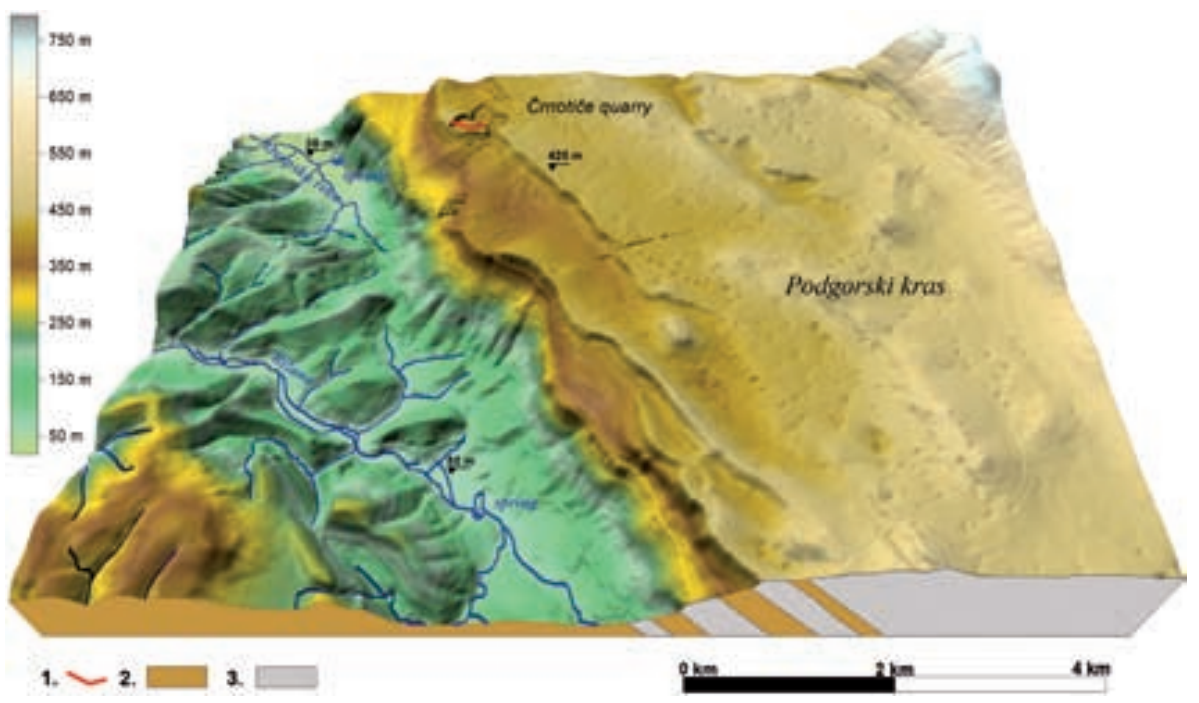

Fig. 7: DEM of the Podgorski kras. Levelled karst surface of Paleocene limestone and some intercalated flysch is in sharp contrast with fluvial relief that developed on Eocene flysch. At the foot of the karst there are the major karst springs where Marifugia cavatica still lives today. The fossil tubes were found in the large cave exposed in the Črnotiče quarry.

Legend: 1. Unroofed cave, 2: Flysch, 3: Limestone.

known tube worm inhabiting continental caves. Stable isotope analysis (Mihevc et al., 2002) of fossil tubes from Črnotiče quarry site is comparable with stable isotope compositions of recent fresh-water species and greatly differs from those of marine serpulids. Marifugia cava-

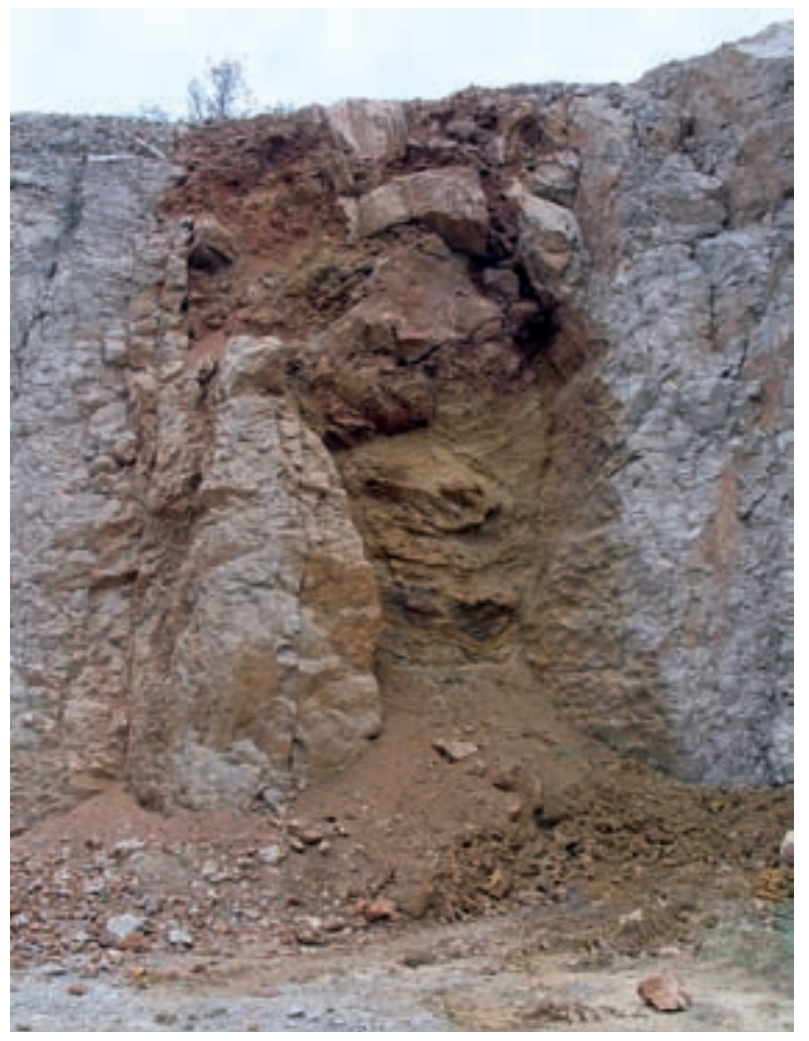
protected by fine fluvial sediments. tica is filter feeder with freeswimming larvae (Matjašič \& Sket 1966). It is widely distributed within the Dinaric Karst and lives in springs of rivers Rižana and Osapska reka which are only few $\mathrm{km}$ and $370 \mathrm{~m}$ apart from the quarry.

Two profiles were analysed within the cave and dated back to $1.76 \mathrm{Ma}$ (Črnotiče I) and 2.5-3.6 Ma (Črnotiče II site) (Bosak \& al. 1999, Bosak \& al. 2004).

Geomorphologic evolution of the plateau shows similarities to those of Kras and Matarsko podolje. Epiphreatic caves of the sinking rivers were filled with sediments; the surface was levelled and uplifted to present altitude. In the quarry there are several unroofed caves or remains old caves. The evolution of vertical shafts with dominance of later autochthonous fill resulted from younger vadose speleogenesis and Pleistocene sedimentation.

Fig. 8: The view of the unroofed cave in a quarry face. Lower part of the cave passage was filled with mostly laminated yellowish brown fluvial sediments. Upper part is filled with flowstone. The karst denudation already unroofed the cave, so that the flowstone is exposed to the surface. Tubes of Marifugia cavatica are on the scalloped walls in the lower part of the cave profile, which were 


\section{CONCLUSIONS}

Three different relief settings on the Kras, Matarsko podolje and Podgorski kras plateau show quite similar evolution. There are old caves present everywhere, which are now exposed by denudation. They were epiphreatic caves that were formed by sinking rivers, bringing allogenic sediments to caves. At the end of the morphogenetic phase all these caves were completely filled with fluvial sediments. This indicates the diminishing of the gradient in the whole area. After the caves were filled the three areas were levelled. Planation occurred in the similar conditions, most likely close to the level of the karst water.

Diminishing of the gradient which ended with planation could mean the same tectonic phase which ended at about $6 \mathrm{Ma}$ ago. After that a new tectonic phase started. Three areas faced uplift and tilting for several hundreds meters. The uplift was stronger in the SE part of the area. Karst denudation was evenly lowering the surface, so the surface remained well preserved, dissected on central parts of karst with dolines, which represent few percent of total area only. The even denudation exposed former caves to the surface. Some of them are filled with sediments, from some sediments were washed away or were never filled.
On the edges of Matarsko podolje there were several sinking streams shaping blind valleys. Their incision was controlled by the piezometric level of the water in karst or the Matarsko podolje and by the tectonic uplift, they are getting deeper towards SE. Tilt of planation surface, different depth and asymmetric or fossil blind valleys are clear indicators of the recent tectonics.

Ages of sediments in the unroofed caves and the morphological datations are in accordance with the ages of main tectonic phases. From these data we can conclude that the oldest elements of the relief are the unroofed caves. The blind valleys are of same age even if they differ by the dimensions. The main process on the surface is even denudation and formation of dolines that form only small proportion of the surface.

The remains of tubes of Marifugia cavatica preserved in a quarry, high above the recent water caves indicate that the karst environment suitable for cave animals has been present for at least $6 \mathrm{Ma}$ and that there was no interruption from the time of the formation of the caves in the Črnotiče quarry and drop of water table and/or tectonic uplift for at least $370 \mathrm{~m}$.

\section{REFERENCES}

Absolon, K. \& S. Hrabe, 1930: Über einen neuen Süsswasser-Polychaten aus den Höhlengewässern der Herzegowina. - Zool. Anz., 88, 9-10, 259-264.

Aguilar, J. P., Crochet J.Y., Krivic K., Marandat B., J. Michaux J., Mihevc A., Šebela S. \& B. Sige, 1998: Pleistocene small mammals from karstic fillings of Slovenia. - Acta carsologica, 27/2, 141-150, Ljubljana.

Bosak P., Pruner P., \& N. Zupan Hajna 1998: Palaeomagnetic research of cave sediments in SW Slovenia. Acta carsologica, 1998, let. 27, št. 2, str. 151-179.

Bosak P., Mihevc A., Pruner P., Melka K., Venhodová D. \& A. Langrová, 1999: Cave fill in the Črnotiče Quarry, SW Slovenia: Palaeomagnetic, mineralogical and geochemical study. - Acta carsologica, 28/2, 2, 15-39, Ljubljana.

Bosák, P., Mihevc A. \& P. Pruner 2004: Geomorphological evolution of the Podgorski Karst, SW Slovenia: contribution of magnetostratigraphic research of the Črnotiče II site with Marifugia sp. - Acta carsologica, 2004, letn. 33, št. 1, str. 175-204, Ljubljana.
Cvijić, J., 1924: Geomorfologija I, 324, Beograd.

Fodor L. Jelen B., Marton E., Skaberne D., Čar J. \& M. Vrabec, 1998: Miocene-Pliocene tectonic evolution of the Slovenian Periadriatic fault: Implications for Alpine-Carpatian extrusion models. - Tectonics, vol. 17, 5, 690-709.

Gams, I., 1962: Meritve korozijske intenzitete v Sloveniji in njihov pomen za geomorfologijo, Geografski vestnik 34/1962, 3-20, Ljubljana.

Gospodarič R., 1985: On the spelogenesis of Divaška jama and Trhlovca Cave. - Acta carsologica, XIII: 5-32, Ljubljana.

Gospodarič R., 1988: Paleoclimatic record of cave sediments from Postojna Karts. - Ann. Soc. geol. Belg., 111, 91-95.

Grund A., 1914: Der geographishes zyclus um Karst. Zeitsch. d. Gesell f. Erdkunde, S. 621-640, Berlin

Habič P.,1982: Kraški relief in tektonika. Acta carsologica, 4, 23-43, Ljubljana. 
Knez M. \& T. Slabe, 2005: Unroofed caves are an important feature of karst surfaces: examples from the classical karst. - Z. Geomorphol., 46, št. 2, str. 181191

Kratochvil, J., 1939: Marifugia cavatica edini sladkovodni serpulid, ostanek starodavnega živalstva na jugoslovenskem krasu. - Proteus, 6, 92-96, Ljubljana.

Matjašič, J. \& B. Sket, 1996: Developpement larvaire du Serpulien cavernicole Marifugia cavatica Absolon et Hrabe. - Int. J. Speleol., 25B, 1, 9-16, L'Aquilla.

Melik, A., 1955: Kraška polja Slovenije v pleistocenu. - Dela Inštituta za geografijo SAZU, 3, 1-163, Ljubljana.

Mihevc, A., 1993: Contact karst of Brkini Hills. - Acta carsologica, 23, 100-109, Ljubljana

Mihevc, A., 1996: Brezstropa jama pri Povirju. - Naše jame 38, 92-101, Ljubljana.

Mihevc, A. \& N. Zupan Hajna, 1996: Clastic sediments from dolines and caves found during the construction of the motorway bear Divača, on the Classical Karst. - Acta carsologica, 25, 169-191, Ljubljana.

Mihevc, A. Slabe T. \& S. Šebela, 1998: Denuded cavesan inherited element in the karst morphology; the case from Kras. - Acta carsologica, 27/1, 165-174, Ljubljana.

Mihevc, A., 1999: The caves and the karst surface-case study from Kras, Slovenia. - Etudes de géographie physique, suppl. XXVIII, Colloque européen-Karst 99, 141-144.

Mihevc, A., 2000: Fosilne cevke iz brezstrope jame - verjetno najstarejši ostanki jamskega cevkarja Marifugia (Annelida: Polychaeta). - Acta carsologica, 29/2, 261-270, Ljubljana.

Mihevc, A., 2001: Speleogeneza Divaškega krasa. - Zbirka ZRC, 27: 1-180. Ljubljana.

Mihevc, A. Sket B., Pruner P. \& P. Bosák, 2001: Fossil remains of a cave tube worm (Polychaeta: Serpulidae) in an ancient cave in Slovenia. - Proc., $13^{\text {th }}$ International Speleological Congress, $4^{\text {th }}$ Speleological Congress of Latin America and the Carribean, $26^{\text {th }}$ Brazilian Congress of Speleology, Brasilia, July 1522, 2001, 20-24, Brasilia.
Mihevc, A., Bosak P. Pruner P. \& B. Vokal 2002: Fossil remains of the cave animal Marifugia cavatica in the unroofed cave in the Černotiče quarry, W Slovenia. Geologija, 45, 2, str. 471-474, Ljubljana.

Pruner, P., Bosák P. Mihevc A. Kadlec J. Man O. \& P. Schnabl, 2003: Preliminary report on palaeomagnetic research on Račiška pečina Cave, SW Slovenia. - 11th International Karstological School „Classical Karst“. Karst Terminology. Guide booklet of the excursions and abstracts of lectures or poster presentations, Postojna, July 2003: 35-37. Postojna.

Radinja, D., 1972: Zakrasevanje v Sloveniji v luči celotnega morfogenetskega razvoja. Geografski zbornik, 13, SAZU, Ljubljana.

Roglič, J., 1957: Zaravni u vapnencima. Geografski glasnik 19, 103-134, Zagreb.

Sket, B., 1970: Über Struktur und Herkunft der unterirdischen Fauna Jugoslawiens. - Biol. Vestn., 18, 6978, Ljubljana.

Slabe, T., 1997: Karst features discovered during motorway construction in Slovenia. - Environ. geol. (Berl.), 1997, letn. 32, št. 3, str. 186-190.

Vrabec, M., \& L. Fodor, 2006: Late Cenozoic tectonics of Slovenia: structural styles at the Northeastern corner of the Adriatic microplate. The Adria microplate: GPS geodesy, tectonics and hazards, - NATO Science Series, IV, Earth and Environmental Sciences, vol. 61). Dordrecht: Springer, 151-168.

Zupan Hajna, N., 1991: Flowstone datations in Slovenia. - Acta carsologica, 1991, let. 20, str. 187-204. 